\title{
sciendo \\ CUSTOMER LOYALTY ON THE INSURANCE SERVICES MARKET IN POLAND
}

\section{LOJALNOŚĆ KLIENTÓW NA RYNKU USŁUG UBEZPIECZENIOWYCH}

Beata Nowotarska-Romaniak, PhD, Assoc. Prof.

University of Economics in Katowice, College of Management, Department of Marketing,

Poland, ul. ks. bpa S. Adamskiego 7, 40-069 Katowice

beata.nowotarska-romaniak@ue.katowice.pl o ORCID: 0000-0003-3563-2596

DOl: 10.2478/minib-2020-0018

\section{ABSTRACT}

Insurance companies are currently carrying out tasks related to building trust, image creation and giving distinctive features to intangible insurance services, which is associated with paying more attention to the packaging of the service than to the service itself. The packaging of the insurance service consists of people, the appearance of branches, the availability of insurance services and flexibility in customer service. For insurance companies, the knowledge of not only marketing practice, but also the knowledge about customer behaviours or factors affecting their loyalty is becoming important. The purpose of the article is to review the loyalty on the insurance services market in Poland and to examine the factors influencing it. The article discusses the methods of testing customer loyalty on the insurance services market. On the other hand, based on the results of the survey, factors affecting customer that may affect customer loyalty satisfaction are presented. 


\section{ABSTRAKT}

Zakłady ubezpieczeń realizują obecnie zadania związane z budowaniem zaufania, kreowaniem wizerunku oraz nadaniem niematerialnym usługom ubezpieczeniowym cech wyróżniających, co wiąże się ze zwróceniem uwagi bardziej na opakowanie usługi niż na samą usługę. Na opakowanie usługi ubezpieczeniowej składają się ludzie, wygląd placówek, dostępność usług ubezpieczeniowych, elastyczność w obsłudze klienta. Dla zakładów ubezpieczeniowych istotna staje się wiedza w zakresie nie tylko praktyki marketingowej, ale również wiedza na temat zachowań klientów czy też czynników wpływających na ich lojalność. W artykule zostały omówione metody badania lojalności klientów na rynku usług ubezpieczeniowych. Natomiast na podstawie wyników badania ankietowego przedstawiono czynniki wpływające na zadowolenie klienta, które mogą wpłynąć na jego lojalność.

\section{Słowa kluczowe: lojalność, usługi ubezpieczeniowe, klient}

JEL: $113, \mathrm{~J} 11$

\section{Introduction}

Customer behaviour forms the basis of the company's loyalty activities. The knowledge of the process of loyalty building plays an important role in the activities of an insurance company. Loyalty is a complex, interdisciplinary category and thus it is difficult to be clearly defined. The definition of loyalty is constantly being reinterpreted, because there are many doubts in the way it is described and this generates difficulties when comparing the results of research. The freedom that prevails when interpreting issues related to customer loyalty has negative impact on researches into existing regularities in customer behaviour (Chłodnicki \& Rogoziński, 2006, pp. 44-45).

In many publications, the authors do not undertake to define this concept, while others treat loyalty in different ways. Loyalty from the 
company's point of view is considered as regular buying of services, putting the company in a positive light by customers and taking into account purchases in a given company when the need arises. Many literature references do not mention the importance of customercompany relations, which is a basis for creating loyalty (Chłodnicki \& Rogoziński, 2006, p. 46).

Loyalty can be understood as the relationship between the client and the company for a long period of time. Clients establish a relationship taking into account cognitive and affective factors, thanks to which the value of relations between clients and the company is increasing. By focusing on gaining customer loyalty, a company can get a higher return on business. Loyalty is associated with attachment, reliability, faithfulness and commitment. The shortest definition means faithfulness and devotion to a company or person (Kopaliński, 1998. p. 306).

Loyal customer means a person who makes regular, repetitive purchases, uses products or services offered by a company, spreads positive information about this company and is resistant to promotional activities of competing companies (Rudawska, 2007, p. 51).

A loyal customer is a customer "attached" to the company, unyielding to the actions of competitors (the so-called customer difficult to acquire) and representing the interests of their company on the market (Altkorn \& Kramer, 1990). Therefore, we can be considered a loyal customer when we purchase the same services always in the same company. Loyal customer also gives positive opinions about the chosen company, encourages other clients to use the services of this company and also is resistant to competitive activities of the competition. The issue of customer loyalty plays a significant role in companies that have direct contact with the final purchasers of products or services. This way, the real success have those companies whose customers make repetitive purchases.

It was noticed that customers are more likely to shop in one company. They can also purchase products for a higher value only when they feel satisfied with previous experiences in the company (Chłodnicki \& Rogoziński, 2006). It can be seen that the clients also become loyal to the company when they receive services that fully satisfy them. The degree of attachment to the company depends on satisfaction with the quality of services. Customers who are satisfied with the quality of services make 
further purchases in the given company. The company's loyalty is also influenced by the fact that the company shows interest to the client, providescompetent service and meets client's needs. Loyalty has been a concept used in marketing, because it is very important to keep regular customers who are cheaper than acquiring new ones due to lower costs connected with the flow of information, promotion and service. There is a fairly widespread belief that the increase in customer satisfaction translates into an increase of their loyalty, which affects the size of the profit (Doyle, 2003, p. 100). Companies that currently operate in a competitive environment and deal with increasingly demanding, aware customers must strive not only to satisfy the customers, but to delight them. Only such a customer can remain loyal to the company and recommend it to other clients. Satisfied customer can still look for other opportunities and benefits in other companies. On the other hand, delighted customer will be loyal and will come to their company first, even if the company does not offer such service yet. Loyal customers will be a source of new ideas, helping to create a new service to meet their needs. Therefore, knowledge about customer satisfaction and their loyalty is very important for the company. Customers on the insurance services market are increasingly demanding and are able to use websites of the insurance companies and make comparisons of the offers or the amount of insurance premiums. For that reason, it is extremely important to create such a bond with the customer that would be a true definition of the customer loyalty in the insurance company.

\section{Methods for checking customer loyalty on the insurance services market}

Loyalty is associated with attachment, reliability, faithfulness and commitment. Insurance companies should measure their customers' loyalty. As part of these tests, the most common measurement is individual customer relations. Most often, the frequency, the repeatability and the quantity of purchases of insurance policies. This study allows you to examine the lack or existence of loyalty, however, without explaining the behaviours of such actions or the feelings of customers. 
The divided indicators for measuring customer loyalty into three categories that can be used in the insurance services market are as follows (Jones \& Sasser, 1995, p. 97):

- the intention to make repeated purchases with the same insurance company,

- the possibility of a client recommending "his" insurance company to others,

- the examination of basic customer behaviours such as the frequency of shopping, continuation of insurance in the same insurance company, how long he or she was a customer of the company or when was the last time he made the purchase.

Customer Satisfaction Index (CSI) and TRI*M Index, Net Promotor Score (NPS) methods are also used to test customer loyalty and satisfaction. NPS is a method of measuring how many clients of a given company will recommend it to their friends. The CSI method is used in marketing to determine the level of customer satisfaction with products or services offered by the company. This method is relatively simple to calculate, but gathering complete, reliable and useful information requires quite advanced marketing research. TRI*M is a method of testing customer loyalty, which consists of two tools: TRI*M map and TRI*M index. The TRI*M index is a quantitative measure of consumer satisfaction and attachment (expressed by one number). The TRI*M map identifies those factors that determine customer loyalty (Nowotarska-Romaniak, 2013, p. 108).

Net Promoter Score is a method used to measure customer loyalty. It was developed by Frederick F. Reichhelda in cooperation with research companies and described in details` in the article "The One Number You Need to Grow" (Reichheld, 2003, pp. 8-10). His idea is to ask the client one question: "How likely is it that you would recommend [company $\mathrm{X}$ ] to your friend or colleague?". The respondent marks the answer on an 11-point scale: $0-$ I will not recommend it at all, $10-$ I will certainly recommend it. Then all study participants are divided into:

- Promoters - enthusiastic loyal customers who will recommend the company and drive its development, 
- Passives - satisfied people, but not loyal, are susceptible to competitive offers,

- Detractors - dissatisfied customers, will not recommend us.

Next, we use the indicator to count the "promoters"' share in our study and subtract the "detractors"' share from it. The result we get is the Net Promoter Score. The higher and the more positive value of the indicator, the better for the company being surveyed.

Insurance companies in Poland use this indicator to study:

- focusing on the client's emotions and feelings related to the company, which is very restrictive, because only clients who rate the insurance company at 9 and 10 are considered by the company as true clients.

- all customers are asked the same question and then analyzed, with what is most strong association with the insurance company $\mathrm{X}$, with what area, department and whether their feelings are positive or negative.

- studies are carried out on a continuous basis, on a few hundred samples per month: after purchasing a life and property policy, after the liquidation of damage, on the next anniversary of having a life policy, after paying the premium refund, after partial purchase, changing the premium allocation or after a medical visit.

- NPS requires listening, learning and changes thanks to feedback from the client. Insurance companies in Poland conduct research on a quarterly basis, at the same time comparing the effects of actions taken by the company in order to improve cooperation with their clients. There is little research on the Polish insurance market about customer loyalty. They mainly concern information on factors influencing the demand for insurance services or factors determining the choice of insurance services and which insurance services are of the biggest interest (Nowotarska-Romaniak, 2009). 


\section{Factors influencing customer loyalty in the insurance services market}

Insurance companies become competitive when they skilfully use the factors inherent in their internal structure or through external factors. This allows not only to create a competitive advantage, but also to study the factors influencing customer loyalty (Walczak, 2010, p. 7).

Factors affecting customer loyalty include endogenous and exogenous factors. Endogenous factors directly affect customers. They include: the values obtained by purchasing insurance services from insurance companies, the degree of involvement in the active acquisition, or the dangers that may arise. However, exogenous factors are not dependent on customers. They focus only on the characteristics of the company and the services offered (Kwiatek, 2007, pp. 38-39).

\section{Factors affecting loyalty}

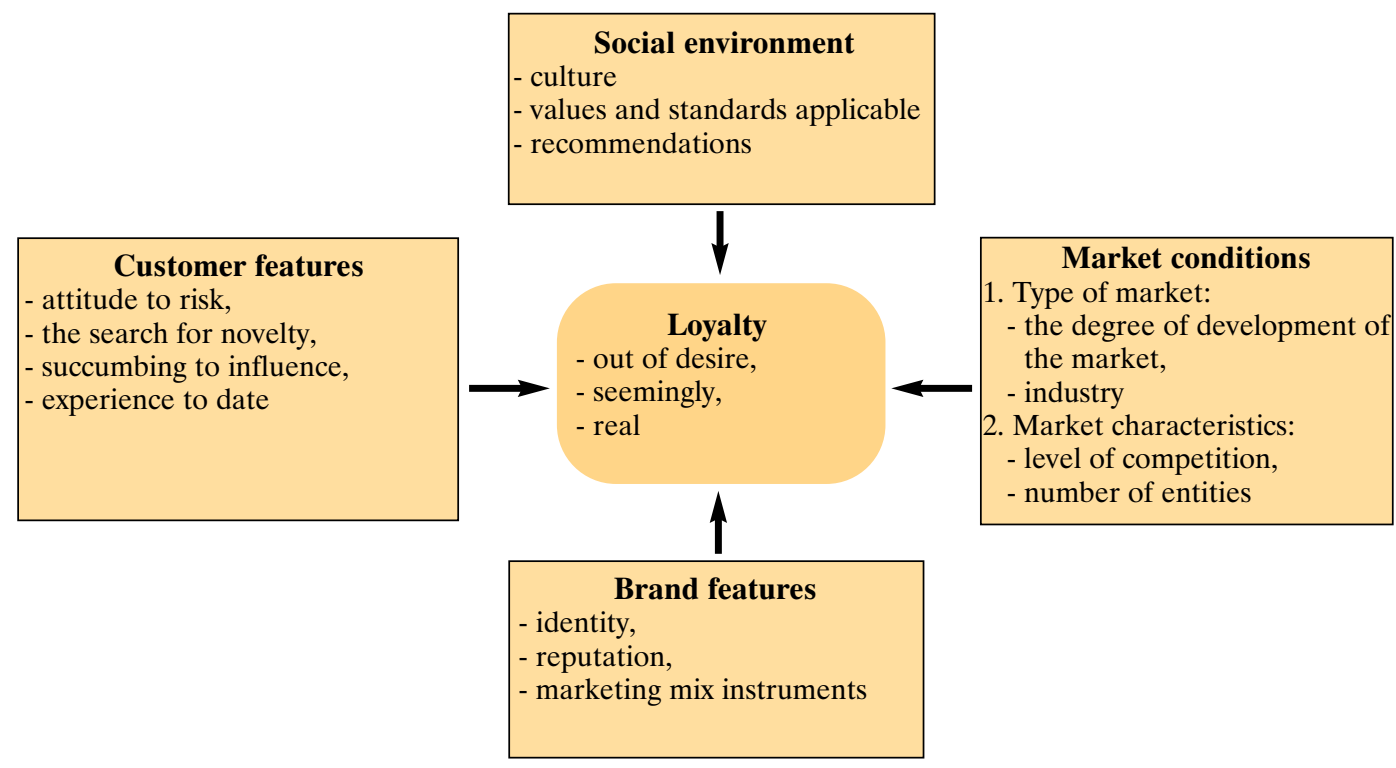

Source: Kwiatek, 2007, p. 39.

According to P. Kwiatek, customer loyalty is influenced by such factors as: customer characteristics, social environment, market conditions and 
brand characteristics (see Figure1). These are factors that interweave or determine each other.

Knowing the factors affecting customer loyalty and monitoring loyalty in the insurance services market is fundamental to providing information that helps insurers to define the level of competitiveness and its impact on the stability of their business. Additionally, customer loyalty monitoring provides information about the company's market position and helps insurers effectively address customer acquisition and retention strategies. Important information that insurance companies must have in order to be able to monitor customer loyalty is presented in Table 1.

\section{Table 1. Important for loyalty testing information about the customer of insurance companies}

\begin{tabular}{|c|c|c|}
\hline No. & Content of the information & Type of information \\
\hline 1. & Basic demographic information & $\begin{array}{l}\text { Age of the holder of the insurance service } \\
\text { Sex } \\
\text { Address of residence } \\
\text { Number of household members }\end{array}$ \\
\hline 2 & Basic information about insurance & $\begin{array}{l}\text { Customer's cooperation with an insurance company } \\
\text { (period of cooperation and continuation of insurance) } \\
\text { Number and type of policies held Additional benefits that the } \\
\text { customer gets for continuing insurance in the same insurance } \\
\text { company (lower premiums, discounts, bonuses) }\end{array}$ \\
\hline 3 & Information about the service insurance & $\begin{array}{l}\text { Scope of cover } \\
\text { Premium rate and method of paymentInformation on changes } \\
\text { in the amount of premiums on a going concern basis }\end{array}$ \\
\hline 4 & Claims & $\begin{array}{l}\text { Claims submitted to an insurance service provider } \\
\text { Loss elimination process } \\
\text { Compensations paid } \\
\text { Dates of claims and circumstances in which claims occurred }\end{array}$ \\
\hline 5 & Cancellation & $\begin{array}{l}\text { Reasons for cancellation of an insurance contract } \\
\text { Foreign firms involved in the cancellation }\end{array}$ \\
\hline 6 & Customer Satisfaction Level & $\begin{array}{l}\text { From the amount of contributions } \\
\text { From the bonus system } \\
\text { Loss adjustment process } \\
\text { Customer service } \\
\text { Satisfaction with the whole cooperation }\end{array}$ \\
\hline
\end{tabular}

Source: own elaboration based on Guillen, Nielsen, Perez-Marin, 2008, pp. 207-218. 
Customer information in the insurance services market plays a very important role in loyalty research. It is necessary to know the data concerning whether the customer withdrew from the insurance service because the risk for the policyholder ceased to exist (e.g. sale of a car) or signed a contract with another insurance company after the end of the insurance period (e.g. for a specific property or a car). The increase in customers' purchasing funds affects the increase in the scope of the customer's decisions and the variety of insurance services to satisfy them. It should be remembered, however, that the customer's behaviour is characterised by variability and susceptibility to external factors and the purchase of a service does not end the process of the customer's behaviour. An important role is played by the process of selling the insurance service and its evaluation after the purchase. A very important process is the loss adjustment and assessment of the process by the customer. This stage seems to be particularly important for insurance companies, because it helps shape opinions on insurance by the customer and then decides on further cooperation with the insurance company, which affects the future loyal behaviours of the customer. Therefore, a very important activity of insurance companies is the study of customer behaviour in the insurance sector, including customer loyalty to these companies.

\section{Survey of customer loyalty in the insurance services market}

The insurance services market is highly competitive, both in terms of the insurance companies themselves and their offer. These companies offer life and non-life insurance services to existing and potential customers. The knowledge of customer loyalty to insurance companies is very important. Therefore, to meet the needs of this article, the author conducted the survey on 10-20 May 2019, by means of an interactive survey (www. Docs.google.com), displayed on a social networking platform Facebook. The survey was addressed to adults who were customers of insurance companies.The selection of the sample was random and purposeful. The questionnaire contained three metric questions (gender: women $(59 \%)$, men $(41 \%)$, age: $18-30(39 \%), 31-60(38 \%)$ and above $60(23 \%)$ and 
education: professional (28\%), secondary (37\%), higher (35\%) and five subtopic questions concerning the loyalty test of customers of insurance companies. 187 correctly completed questionnaires were received. The first question referred to the factors which determine a customer's satisfaction with the insurance service he or she uses. The respondents mentioned such aspects as: the amount of compensation received at the moment of an insurance accident, the speed of the loss liquidation process, professional service, ease of access and parking. The level of satisfaction and trust does not guarantee that the customer will buy again from the same insurance company. But it gains the trust of customers, we gain the loyalty of customers (Nowotarska-Romaniak, 2013).

The next research question was the frequency with which the clients change the insurance companies. The study concerned the users of life insurance, as well as customers buying property insurance. On the basis of a questionnaire survey it can be stated that life insurance customers do not change their insurance company (82\%). If they give up anything, it is the continuation of life insurance. In the case of non-life insurance (49\%), however, the insurance company did not change (47\%), changed $(4 \%)$ and does not remember (4\%). The results show that there is a large group of customers who do not change their insurance company, are attached to it or are loyal to it. At the same time, there is a large group of customers who change insurance companies. On the basis of the survey it can be stated that it is caused by comparing prices $(74 \%)$ or because of dissatisfaction with the loss adjustment process carried out (68\%). Analysing these results according to the metric, they are comparable to the total results. An important question was what factors influence the satisfaction of customers of insurance companies, which may influence loyalty (see Figure 2).

The factors influencing customer satisfaction with insurance companies that may influence loyalty are: the amount of compensation and the speed of the loss adjustment process. The amount of insurance premium is only the third factor in the order. Insurance companies have groups of loyal customers. Customers of life insurance companies (87\%) declare that they are loyal to their companies. On the other hand, customers of non-life insurance companies (59\%) declare that they are loyal. Depending on age, the loyalty index varies. The most loyal are the elderly, who definitely declare that they will use the services of "their" insurance company. Young 
customers are the least loyal (58\%) who, when buying insurance services again, despite being satisfied with the cooperation to date, re-examine the market offer. Gender analysis shows that women are more loyal (78\%) than men (57\%). Research has confirmed that insurance companies have loyal customers. It is important that they are able to take care of them, because this loyalty can quickly be undermined by competing insurance companies offering additional benefits to customers.

\section{Figure 2. Factors influencing customer satisfaction of insurance companies, which may affect loyalty*}

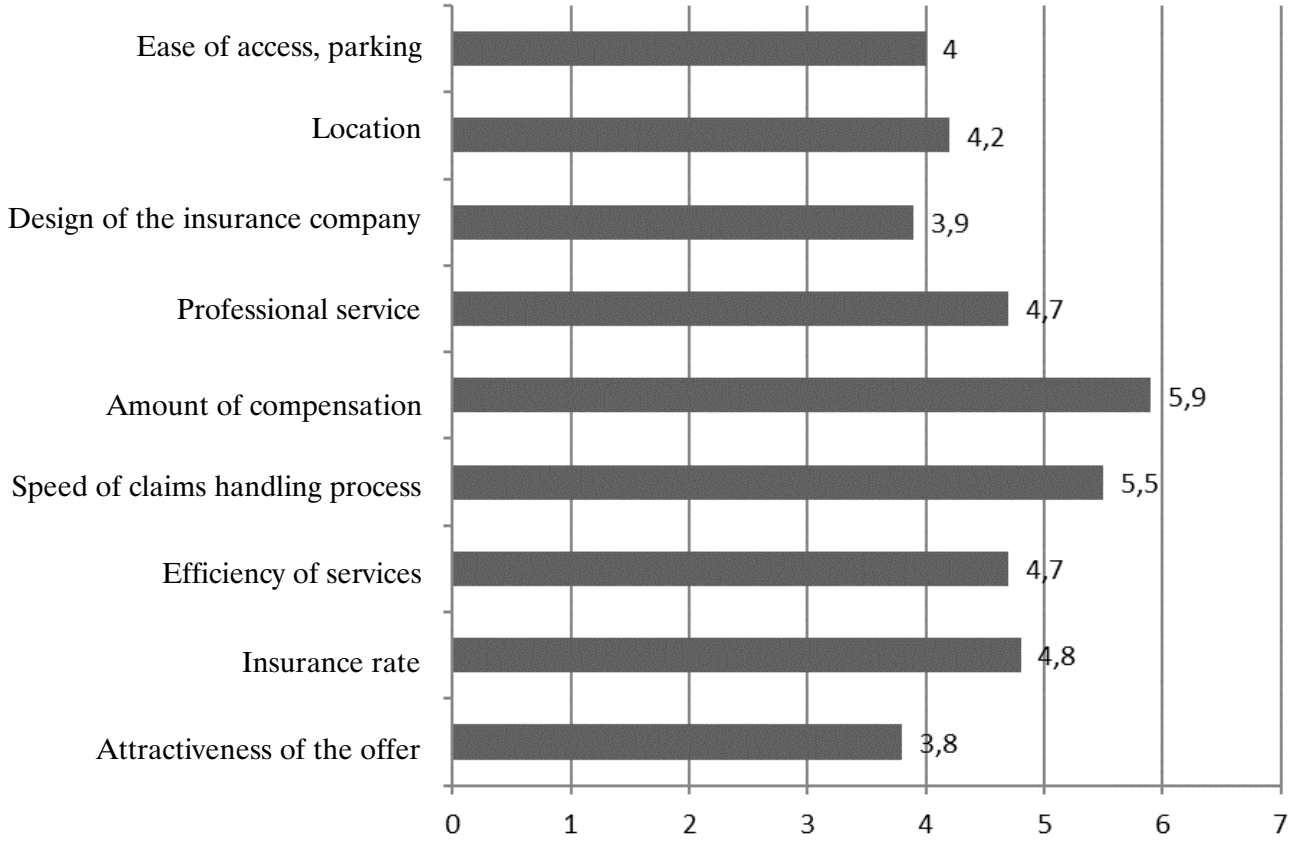

*Arithmetic mean of ratings indicated by customers on a scale from 1 - least satisfied to 6 - most satisfied. Source: own study on the basis of a questionnaire survey.

\section{Conclusion}

Customer loyalty in the insurance services market is an important problem, especially since this market is highly competitive and "fights" for 
customers. Insurance companies need to know and apply factors that influence customer loyalty. Research has shown that a large number of customers, especially older customers, are loyal. Therefore, insurance undertakings should not only offer good insurance services to their loyal customers with a rapid and fair claims handling process, but should also take steps to build up this loyalty, in order to ensure that their loyal customers are well cared for. That is, getting to know the customer and searching for opportunities to make an agreement is fundamental. The possibility of agreement between the seller and the customer allows to discuss and determine the current state of the customer in terms of perceived needs, risks and insurance services.

\section{References}

1. Altkorn, J., Kramer, T. (1990). Leksykon marketingu. Warszawa: Polskie Wydawnictwo Ekonomiczne.

2. Chłodnicki, M., Rogoziński, K. (2006). Zarzadzanie relacjami w ustugach. Zarzadzanie relacjami w ustugach. Warszawa: Difin, Warszawa:

3. Doyle, P. (2003). Marketing wartości. Warszawa: Felberg SJA.

4. Guillén, M., Nielsen, J. P., Pérez-Marín, A. M. (2008). The need to monitor customer loyalty \& business risk in the European insurance industry. Geneva Papers on Risk and Insurance-Issues and Practice, 33(2), 207-218.

5. Jones, T., Sasser Jr, W. E. (1995). Why Satisfied Customers Defect. Harvard Business Review, (2).

6. Kopaliński, W. (1998). Stownik wyrazów obcych i zwrot ów obcojęzycznych. Warszawa: PWN.

7. Kwiatek, P. (2007). Programy lojalnościowe. Budowa i funkcjonowanie. Kraków: Wolters Kluwer Polska.

8. Nowotarska-Romaniak, B. (2009). Loyalty within market of Insurance Service. Economica. Problemy teorii na praktyki, (258), 1139-1144.

9. Nowotarska-Romaniak, B. (2013). Zachowanie klientów indywidualnych w procesie zakupu ustugi ubezpieczeniowej. Warszawa: Wolters Kluwer.

10. Reichheld, F. F. (2003). The One Number You Need to Grow. Harvard Business Review, (December), 8-10.

11. Rudawska, E. (2007). Trwałe relacje z klientem z zasobowej teorii przedsiębiorstwa. Handel Wewnętrzny, (special issue).

12. Walczak, W. (2010). Analiza czynników wpływających na konkurencyjność przedsiębiorstw. E-mentor, 5(37). 
Beata Nowotarska-Romaniak, PhD, University of Economics in Katowice - is a DSc and prof. at the University of Economics in Katowice. She is the author and co-author of several works in the field of health and insurance services and over 150 science publications on the marketing strategies and marketing adaptation for the insurance companies and healthcare units as well as on consumer behaviour on the insurance market, published both in Poland and abroad. She gives lectures and seminars for the managers and workers of the healthcare units, banks and insurance companies. She collaborated in the project: Managerial Support For the Executives of Healthcare Entities co-financed by EU through the European Social Fund. 